E)

I393 INDIAN NOTES NMAI AND MONOGRAPHS

\author{
Edited by F. W. Hodgr
}



A SERIES OF PUBLICA. TIONS RELATING TO THE AMERICAN ABORIGINES

\title{
INDIAN HOUSES OF PUGET SOUND
}

BY

T. T. WATERMAN

AND

RUTH GREINER

E

51

.1393

no. 9

NMAIREF

NEW YORK

MUSEUM OF THE AMERICAN INDIAN

HEYE FOUNDATION

1921

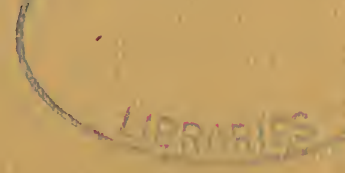


This series of Indian No'res AND MoNOGRAPHS is devoted primarily to the publication of the results of studies by members of the staff of the Museum of the American Indian, Heye Foundation, and is uniform with HisPanic Notes and Monographs, published by the Hispanic Society of America, with which organization this Museum is in cordial coöperation.

Only the first ten volumes of Indian NoteS AND MoNOGRAPHS are numbered. The unnumbered parts may readily be determined by consulting the List of Publications issued as one of the series. 


\section{INDIAN NOTES AND MONOGRAPHS}

Edited by F. IV. Hodge

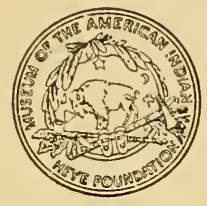

A SERIES OF PUBLICA. TIONS RELATING TO THE AMERICAN ABORIGINES

\section{INDIAN HOUSES OF PUGET SOUND}

BY

T. T. WATERMAN

AND

RUTII GREINER

NEW YORK

MUSEUM OF THE AMERICAN INDIAN

HEYE FOUNDATION

1921 

INDIAN HOUSES OF PUGET SOUND

\author{
BY \\ T. T. WATERMAN \\ AND \\ RUTH GREINER
}





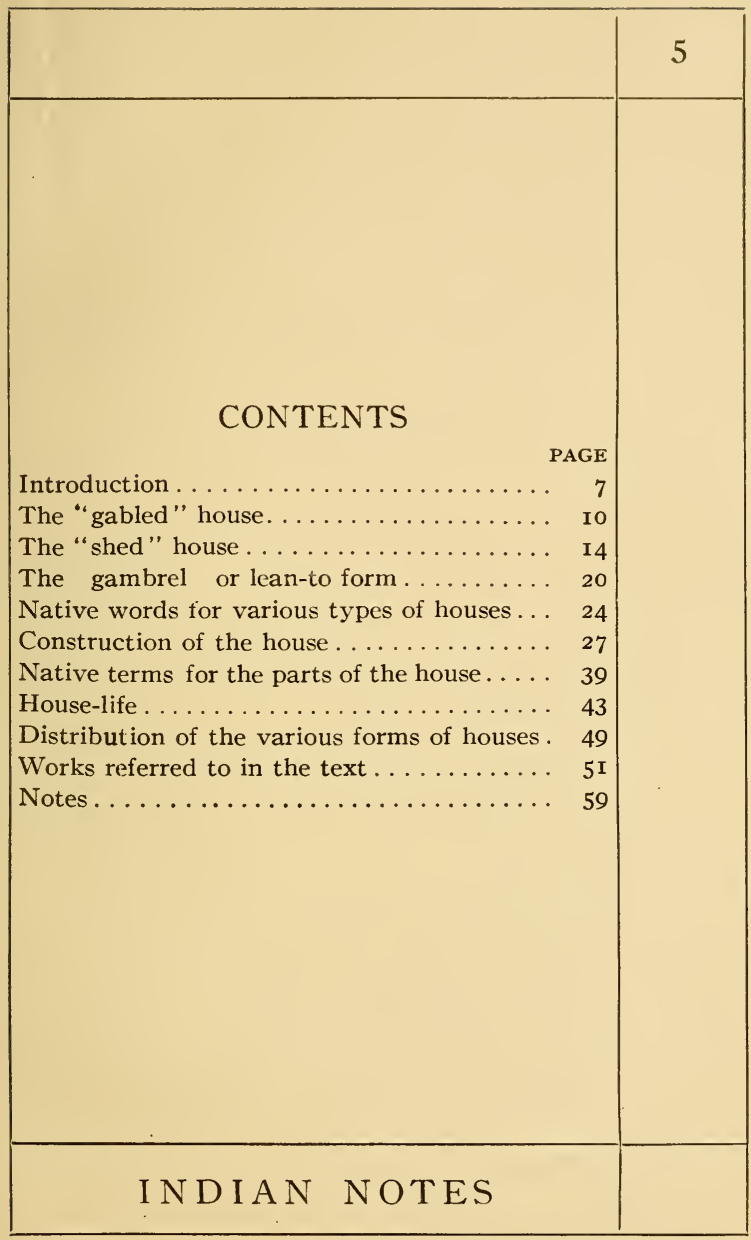





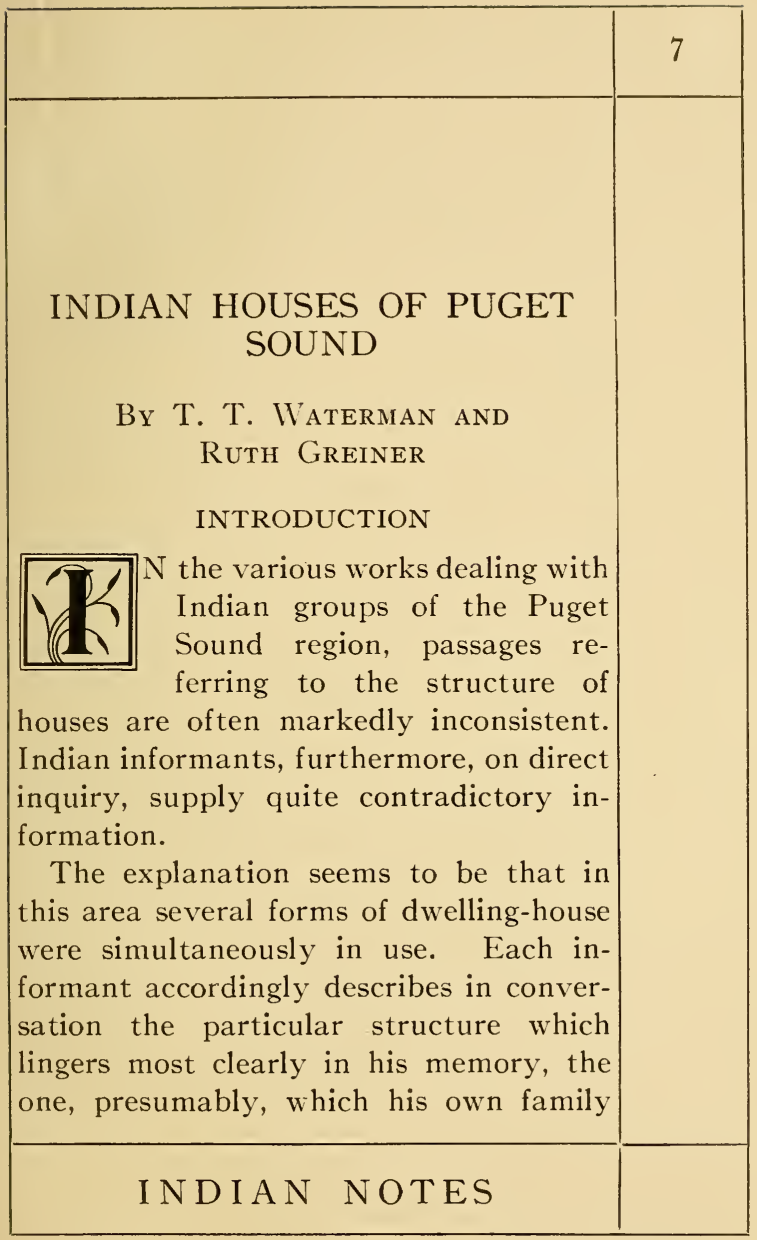




\begin{tabular}{|l|l|}
\hline 8 & $\begin{array}{l}\text { P U G E T S O U N H O US ES } \\
\text { used. Of the various forms of houses, } \\
\text { one seems to have been limited strictly } \\
\text { to the neighborhood about Puget sound; } \\
\text { there seems to be no mention of it in } \\
\text { other regions. This particular form has } \\
\text { never been fully described. } \\
\text { The purpose of the present paper is to } \\
\text { outline the principal features of the houses } \\
\text { used about Puget sound, and to discuss } \\
\text { the distribution of the three forms. The } \\
\text { paper is based on what is said about } \\
\text { houses in the various printcd works which } \\
\text { refer to the Puget Sound people, and on } \\
\text { inquiry made among the Indians, the } \\
\text { latter work being provided for by the } \\
\text { University of Washington. Mr Arthur } \\
\text { C. Ballard, of Auburn, Washington, } \\
\text { handed over to the present authors part } \\
\text { of a very considerable body of material } \\
\text { recorded by himself in the course of } \\
\text { studies among the Indians, for the pur- } \\
\text { pose of comparing results with those } \\
\text { obtained by recent inquiry. The present } \\
\text { paper is accordingly the result of a } \\
\text { three-sided investigation. } \\
\text { The only recognizable structural parts }\end{array}$ \\
\hline & $\begin{array}{l}\text { I N I A N N OT ES } \\
\text { and }\end{array}$ \\
\hline
\end{tabular}




\begin{tabular}{l} 
I N T R O D U C T I O N \\
\hline of Puget Sound houses which have been \\
permanently preserved are, it seens, \\
some roof-planks recently obtained for \\
the Museum of the American Indian, \\
Heye Foundation. If still other portions \\
of houses have been preserved, so much \\
the better. Not a single house is stand- \\
ing at present; and the best example \\
which ever stood in the vicinity of \\
Seattle was destroyed many years ago \\
by employees of the Indian Office. \\
Broadly speaking, there were three \\
forms of permanent houses in use in the \\
area under consideration. One form was \\
an affair with a gabled roof, built, accord- \\
ing to Curtis, only for very wealthy \\
men. The second form of house had \\
what might be called a "shed-roof," \\
with a single pitch. Structures of this \\
second type were very large and quite \\
elaborate. The fact that they had a \\
"shed" roof does not by any means \\
imply that they were makeshift or \\
temporary. The third form had a cen- \\
tral roof, almost flat, with lean-to's \\
added, producing an effect suggesting the \\
\hline A N D M ONOG R A P HS
\end{tabular}




\begin{tabular}{|c|c|}
\hline 10 & PUGET SOUND HOUSES \\
\hline & $\begin{array}{l}\text { "hip" or "gambrel" roofs of European } \\
\text { structures. } \\
\text { THE "GABLED" HOUSE } \\
\text { In this type of structure wall-planks } \\
\text { and roof-planks are said to have extended } \\
\text { horizontally, the plank nearest the crest } \\
\text { of the roof being propped up to form an } \\
\text { exit for the smoke. Denny reproduces } \\
\text { an illustration of questionable value } \\
\text { showing a gabled structure as one type of } \\
\text { Indian house. Her picture indicates } \\
\text { vertical wall- and roof-boards. Little } \\
\text { else has been said about this form of } \\
\text { dwelling, so far as the Puget Sound } \\
\text { region is concerned. A good deal of } \\
\text { information, however, is available about } \\
\text { similar houses in neighboring areas. } \\
\text { Among the tribes to the south and west } \\
\text { of the sound (the Quinault, Chehalis, } \\
\text { Chinook, Clatsop, Wishram), houses of } \\
\text { the same type have the following features: } \\
\text { There is one ridge-pole in the center, } \\
\text { and a doorway consisting of an oval or a } \\
\text { circular hole cut through a plank, in the } \\
\text { end of the structure, which is built "end- }\end{array}$ \\
\hline & I NDIAN NOTES \\
\hline
\end{tabular}




\section{GABLED HOUSE}

on" to the water. ${ }^{3}$ The wall- and roofplanks are sometimes placed vertically, and sometimes (if Mrs Victor is correct ${ }^{4}$ ) horizontally. Most authors describe them as vertical. ${ }^{5}$ Bancroft makes the apparently reasonable remark that usage varied. ${ }^{6}$ In at least one case the wallplanks were vertical and the roof-planks horizontal. This is clearly described by Swan for the Chinook. ${ }^{7}$ IVhere the wallplanks are horizontal, they are held in place by being lashed between two vertical poles. In the region farther to the south, again, wall-planks are invariably vertical and the roof-planks are placed at right angles to the ridge-pole. It would be much more satisfactory for purposes of description if the Indians of this area had limited themselves to one method of disposing their wall- and roof-boards. We must dismiss this particular matter, however, by saying with Bancroft that in the area we are discussing usage was apparently not uniform. This certainly applies to Puget sound, and explains some contradictory notes supplied by Indian informants.

\section{AND MONOGRAPHS}




\begin{tabular}{|c|c|}
\hline 12 & PUGET SOUND HOUSES \\
\hline & $\begin{array}{l}\text { A feature of some importance in Indian } \\
\text { houses is the presence of a pit. From the } \\
\text { Columbia river southward, gabled houses } \\
\text { invariably contain such pits. Lewis and } \\
\text { Clark say that the Chinook house has an } \\
\text { excavation } 4 \mathrm{ft} \text {. deep. Mrs Victor puts } \\
\text { it at } 3 \mathrm{ft} \text {., while Bancroft says } 4 \text { or } 5 \mathrm{ft} \text {., } \\
\text { and Washington Irving, } 6 \mathrm{ft}{ }^{8} \text { Mrs Vic- } \\
\text { tor and Irving mention a ladder by which } \\
\text { the visitor reached the bottom of the pit. } \\
\text { Inquiries indicate that around the Sound } \\
\text { houses also contained pits, though the } \\
\text { printed sources on the Sound area say } \\
\text { little of this feature. } \\
\text { Such facts would suggest that the } \\
\text { gabled structure found on Puget sound } \\
\text { is similar to a form of habitation which } \\
\text { has a very wide distribution to the south- } \\
\text { ward. The size of all houses diminishes } \\
\text { rapidly as we go in that southerly direc- } \\
\text { tion toward the tribes of Oregon and } \\
\text { California. On the Columbia river, for } \\
\text { example, according to Bancroft, they } \\
\text { measured } 25 \text { by } 75 \text { ft. In northern } \\
\text { California the largest gabled houses are } \\
\text { not more than } 8 \text { by } 32 \text { ft. This would }\end{array}$ \\
\hline & I NDIAN NOTES \\
\hline
\end{tabular}




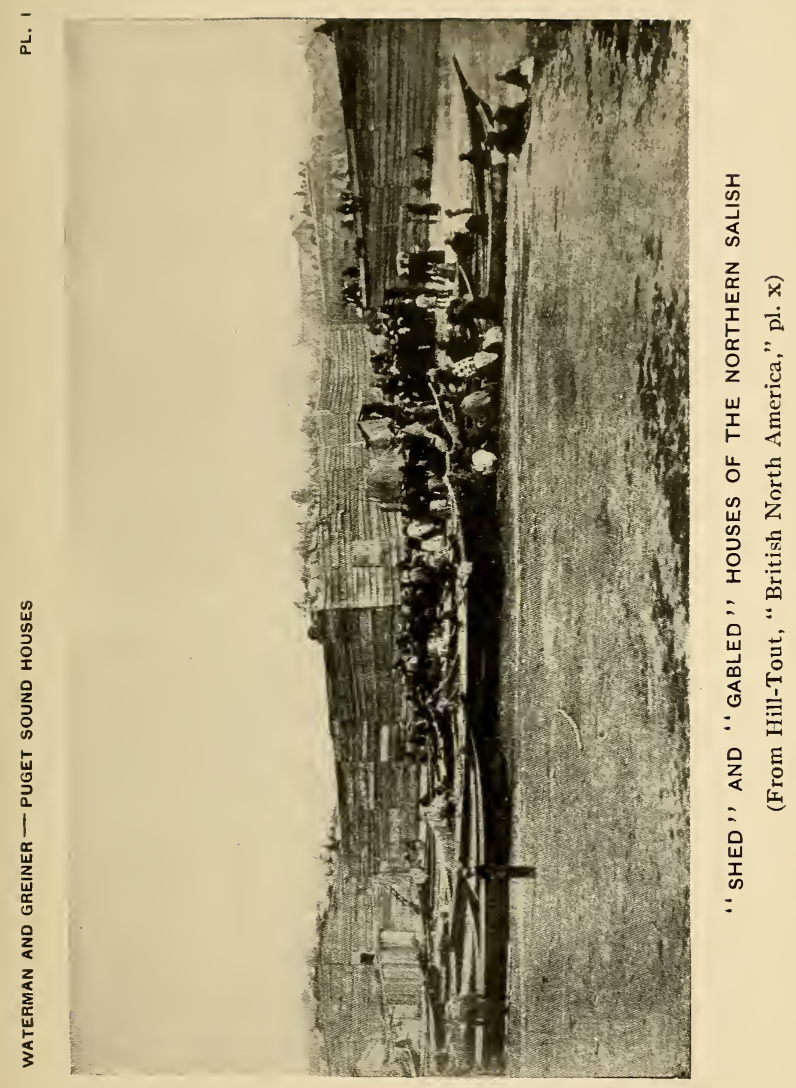





\section{GABLED HOUSE}

raise the inference that the source for the distribution of such houses lies somewhere in the north. Such gabled forms seem not to exist in the area immediately north of Puget sound. On the coast of Washington, gabled houses are not mentioned north of the Quinault. There they are completely supplanted by another form of structure. They do not reappear until we come to the Comox on the eastern side of Vancouver island. Hill-Tout's photographs show the "shed" and "gable" forms standing side by side among the Salish of the British Columbia coast (pl. I). Concerning the distribution of gabled houses, then, it must be noted that they are found in two areas, one of which includes Puget sound and extends southward to California, while the other area extends from the Comox northward for a considerable distance; as a matter of fact, to Prince IVilliam. sound, Alaska. The appearance of one of these gabled structures standing in southern British Columbia is shown in pl. II. The Puget Sound house was much smaller than this.

\section{A ND MONOGRAPHS}




\begin{tabular}{|c|c|}
\hline 14 & PUGET SOUND HOUSES \\
\hline & $\begin{array}{l}\text { THE "SHED" HOUSE } \\
\text { This form seems to have been much } \\
\text { more common on Puget sound than was } \\
\text { the preceding type. It is referred to by } \\
\text { Gibbs as the type characteristic of the } \\
\text { Puget Sound "tribes." The "shed" } \\
\text { house was also employed by the Quilliute } \\
\text { and Makah on the coast of Washington. } \\
\text { To the northward the use of this form } \\
\text { extended over the entire west coast of } \\
\text { Vancouver island, up the east coast to } \\
\text { the Comox (as just remarked), and over } \\
\text { the mainland of southern British Colum- } \\
\text { bia. }{ }^{10} \text { Boas }{ }^{10 a} \text { has given a complete } \\
\text { account of this form of structure as found } \\
\text { among the Lkúngen, or Songish, near } \\
\text { Victoria, B. C., with a diagram of the } \\
\text { separate beams, here reproduced as fig. I. } \\
\text { Captain Cook, in his Voyages, has a } \\
\text { verbal description of those viewed by } \\
\text { him at Nootka sound in April, I778." } \\
\text { Other authorities, such as Myron Eells, } \\
\text { Swan, Simon Fraser, and Jewitt, }{ }^{12} \text { report } \\
\text { such structures briefly, while Curtis }{ }^{13} \text { has } \\
\text { a more systematic description. } \\
\text { The principal peculiarity of these struc- }\end{array}$ \\
\hline & I NDIAN NOTES \\
\hline
\end{tabular}




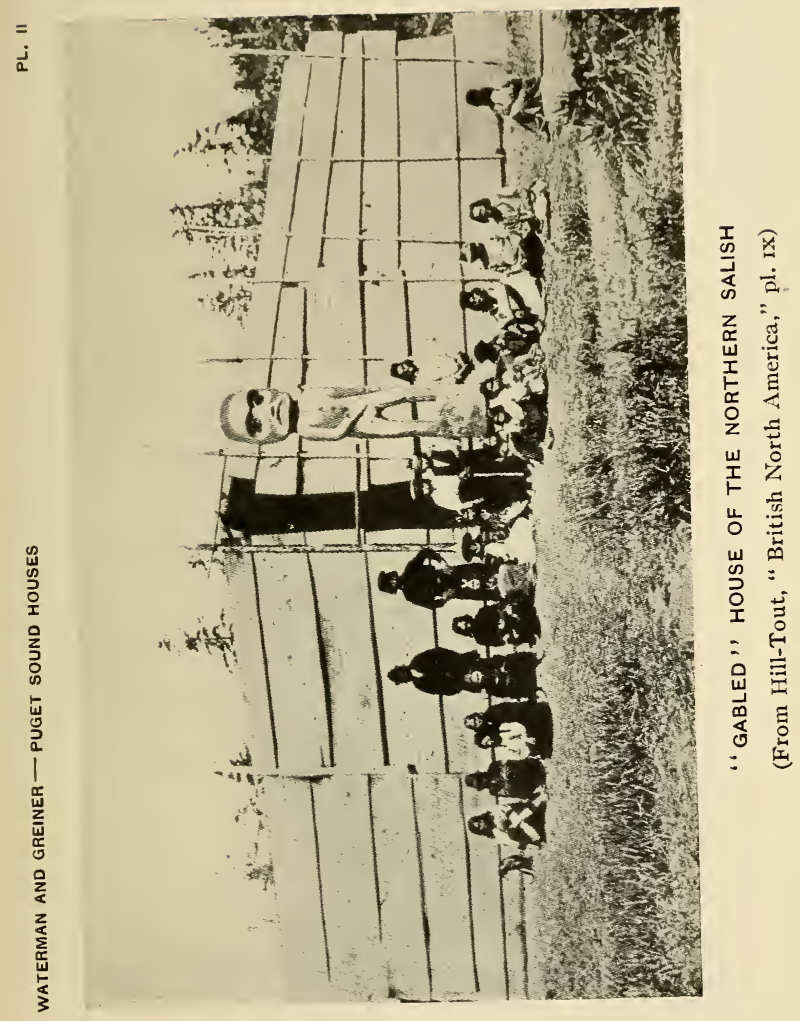





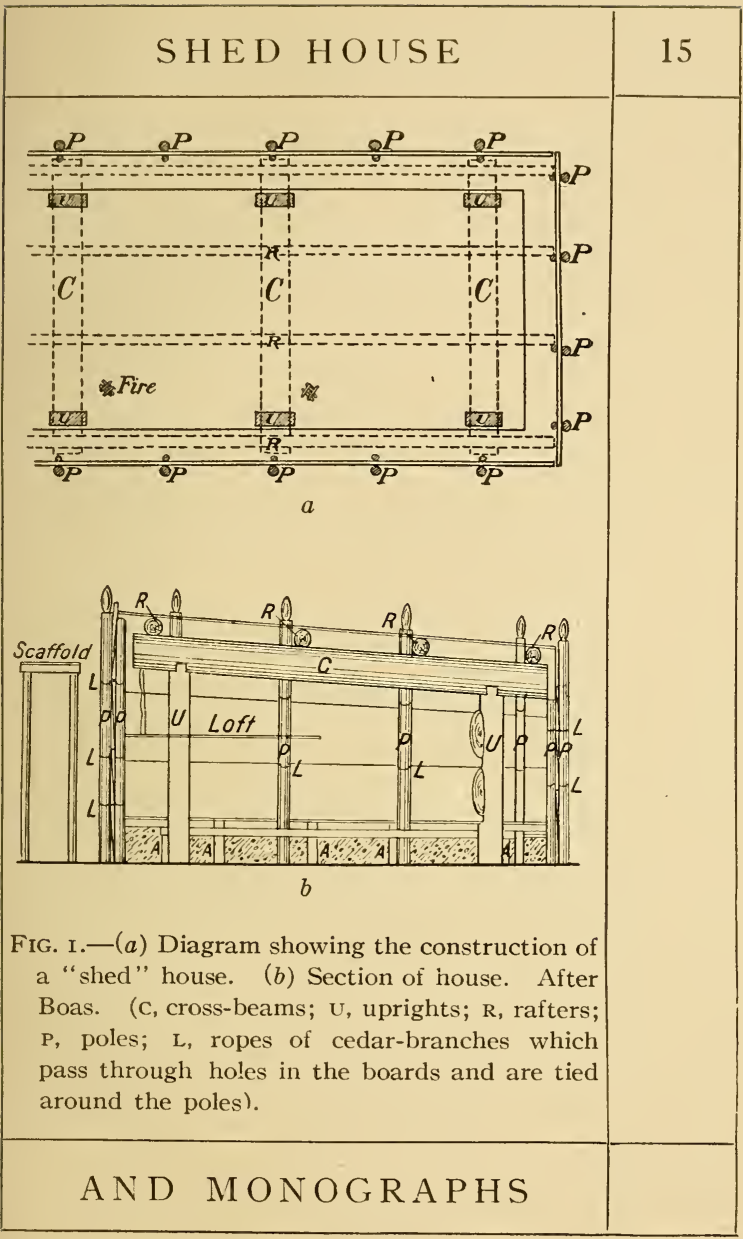




\begin{tabular}{|c|c|}
\hline 16 & PUGET SOUND HOUSES \\
\hline & $\begin{array}{l}\text { tures is that they have a flat roof, with a } \\
\text { single "pitch." Myron Eells describes } \\
\text { this form of structure with the crypto- } \\
\text { grammic phrase, "house with the roof } \\
\text { wholly on one side." } 14 \text { The appearance } \\
\text { of a house similar to the Puget Sound } \\
\text { form is shown in an excellent photograph } \\
\text { published by Hill-Tout }{ }^{15} \text { and here repro- } \\
\text { duced (pl. I). On Puget sound the roof } \\
\text { slopes to the rear. Both Boas and Cap- } \\
\text { tain Cook say that the British Columbia } \\
\text { house slopes from the rear toward the } \\
\text { front. } \\
\text { A noteworthy point concerning this } \\
\text { type of house is the prodigious size which } \\
\text { it sometimes attains. An example of } \\
\text { this type of structure, modified in cer- } \\
\text { tain respects, stood for many years on } \\
\text { the shore of the sound opposite Seattle, } \\
\text { at the Port Madison Indian reservation. } \\
\text { Some of the local historians tell astound- } \\
\text { ing stories of its length. Carlson, writing } \\
\text { in a Bulletin of the University of Wash- } \\
\text { ington, History Series, }{ }^{16} \text { gives its length } \\
\text { as "9oo feet." Costello, in a locally pub- } \\
\text { lished book, extends the length to I,ooo }\end{array}$ \\
\hline & I N DIAN NOTES \\
\hline
\end{tabular}




\begin{tabular}{|c|c|}
\hline SHED HOUSE & 17 \\
\hline $\begin{array}{l}\text { ft. Such dimensions for this particular } \\
\text { building seem to be quite fanciful. } \\
\text { Gibbs, whose monograph is the standard } \\
\text { work on the Puget Sound Indians (which } \\
\text { monograph, by the way, the local writers } \\
\text { seem to have overlooked), gives the } \\
\text { length of this structure as } 520 \text { ft. In } \\
\text { these figures he quotes Goldsborough, } \\
\text { who went inside the edifice in I } 855 \text {, while } \\
\text { the framework was still standing, and } \\
\text { took measurements of all the important } \\
\text { beams. }{ }^{18} \text { Farther north, however, houses } \\
\text { attaining the dimensions cited seem to } \\
\text { have real existence. Simon Fraser saw } \\
\text { what was apparently one of these struc- } \\
\text { tures standing on the river which bears } \\
\text { his name, and says that it was } 646 \text { ft. in } \\
\text { length and } 60 \text { ft. in width, "all under one } \\
\text { roof." } 19 \text { At the mouth of the river he } \\
\text { saw a "fort" I, } 500 \text { ft. long and } 90 \mathrm{ft} \text {. } \\
\text { broad. It is not certain what the form } \\
\text { of the structure was. Possibly it was not } \\
\text { a house, but an inclosure. Hill-Tout } \\
\text { says that he himself knows of a house } \\
\text { more than I,ooo ft. in length. }{ }^{20} \text { Such } \\
\text { gigantic structures are, of course, com- }\end{array}$ & \\
\hline AND MONOGRAPHS & \\
\hline
\end{tabular}




\begin{tabular}{|c|l|}
\hline 18 & $\begin{array}{l}\text { P U G E T S O U N D H O US ES } \\
\text { munal dwellings, as were apparently all } \\
\text { plank-houses of the entire region. } \\
\text { This "shed" form of house seems } \\
\text { always to have been built facing the } \\
\text { water, its long sides parallel to the beach } \\
\text { line. In some cases a number of exits } \\
\text { were provided. The front wall was from } \\
\text { Io to I8 ft. high, and the rear wall some- } \\
\text { what lower, but always greater than the } \\
\text { height of a man. The great width which } \\
\text { these structures had (40 ft. or more), had } \\
\text { the effect of giving the roof a very gentle } \\
\text { pitch. Such a low roof-slope is somewhat } \\
\text { characteristic of the houses built by the } \\
\text { Indians even today (see pl. viII) Hill- } \\
\text { Tout remarks that it was impracticable } \\
\text { to make walls of any structure very tall, } \\
\text { because it was too difficult to lift to great } \\
\text { heights those colossal beams which Indian } \\
\text { usage favored for all buildings. Some of } \\
\text { these beams were } 2 \text { ft. in diameter and } \\
\text { 6o ft. long. A low front wall has as a } \\
\text { natural result a roof that is somewhat } \\
\text { flat. This level roof-space was commonly } \\
\text { utilized for drying fish, and for other } \\
\text { purposes. Pl. I, for example, shows a }\end{array}$ \\
\hline \multicolumn{1}{|c|}{ I N D I A N N OT ES } \\
\hline
\end{tabular}




\section{SHED HOUSE}

scene at a "potlatch," in which the roof of one of these "shed" houses is lined with the spectators and with piles of blankets, the latter intended for distribution. Swan conjectures that the roof is made flat for the express purpose of drying halibut, but this explanation seems very improbable.

There is some uncertainty as to whether all these "shed" houses were constructed over "pits" or excavations. Some of them certainly had pits. Curtis states for the region of Puget sound that the house had a central excavation. In the case of such elongate structures as these buildings, this excavation assumes the form of a wide, shallow trench extending down the length of the dwelling. ${ }^{21}$ This excavation was only a foot deep. Myron Eells supplies corroboration on the presence of a pit. ${ }^{22}$ Other authorities, however, are silent on the matter. The native structures for hundreds of miles to the south and north of the area we are discussing were provided with excavations, as stated by all authorities. ${ }^{23}$ It

\section{AND MONOGRAPHS}




\begin{tabular}{|l|l|}
\hline 20 & $\begin{array}{l}\text { P U G E T S O U N D H O US ES } \\
\text { seems probable that these great "shed- } \\
\text { houses" also had pits, at least typically. } \\
\text { Myron Eells is authority for the state- } \\
\text { ment that this "shed" form was the } \\
\text { oldest style of structure about Puget } \\
\text { sound, and the one most commonly used } \\
\text { in aboriginal days. }{ }^{24} \\
\text { THE GAMBREL oR "LEAN-TO" FORM } \\
\text { On Puget sound a special form of struc- } \\
\text { ture was developed, differing in certain re- } \\
\text { spects from both of those mentioned. We } \\
\text { may perhaps speak of this as the third } \\
\text { style of dwelling. In most points of con- } \\
\text { struction such houses are identical with } \\
\text { the type just discussed. A new and } \\
\text { characteristic feature is a kind of addition } \\
\text { to the structure, in the form of a "lean- } \\
\text { to," which was always added to the rear } \\
\text { of the building, and sometimes extended } \\
\text { clear around it, on all four sides. Thus } \\
\text { is produced a structure of curious form, } \\
\text { which is not known to have been de- } \\
\text { scribed in any other locality. Myron } \\
\text { Eells in a brief note } \\
\text { structure, styling it the "flat-roofed dwel- }\end{array}$ \\
\hline I N D I A N N O T ES \\
\hline
\end{tabular}




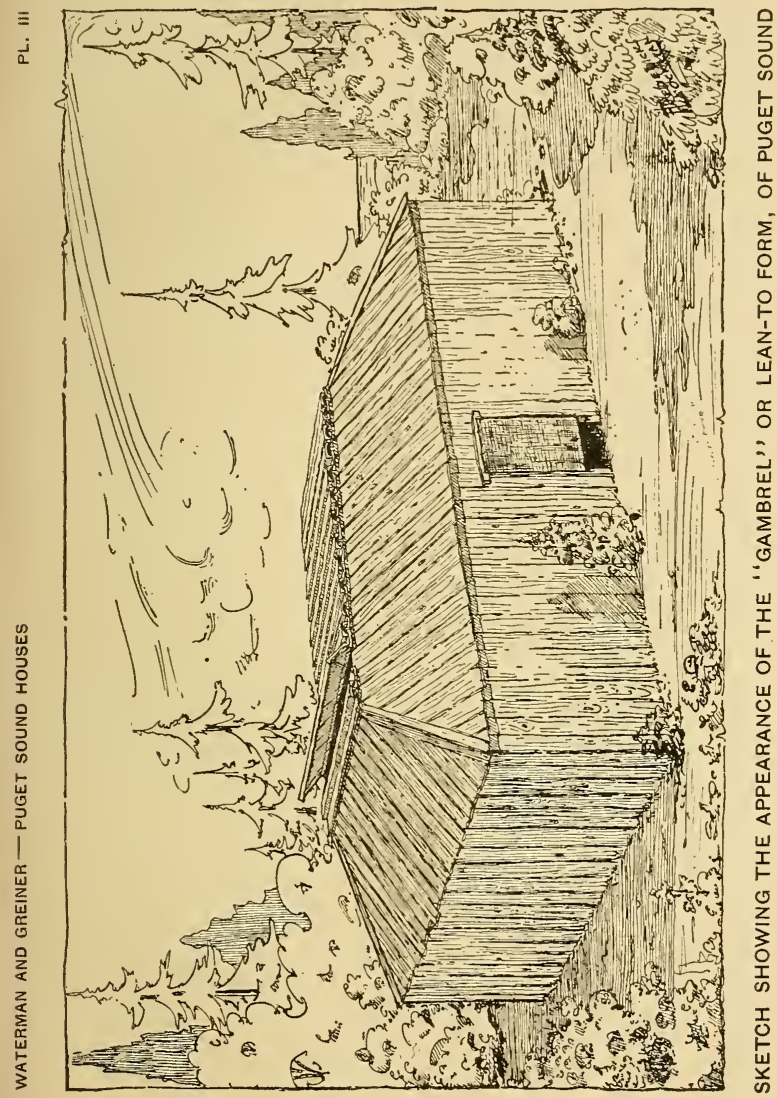



ling house." He says in effect that the roof is composed of two parts: (I) a part made of "clapboards," which generally has a steep pitch; (2) another part made of "long boards." It is this part made of "long boards" which is flat. The relation of the two parts is indicated by an illustration in a book by Miss Denny called Blazing the Way. ${ }^{26}$ This picture, which is apparently a composite, having the background (and possibly the houses) brushed in, is too poor to reproduce. The sketch herewith (pl. III) is based on a model of such a house made many years ago by a middle-aged Duwamish, Peter Rodgers (now deceased), plus some dimensions supplied orally by native informants, particularly by Mr Joe George and Mr Sam Wilson, of Port Madison reservation. Such houses varied greatly n size. The sketch represents one of moderate dimensions.

The principal feature of the structure is a central section of roof which is almost flat. This part is upheld by a very heavy framework, and s covered over with wide

\section{AND MONOGRAPHS}




\begin{tabular}{|l|l|}
\hline 22 & $\begin{array}{l}\text { P U GE T S O U N D H O USES } \\
\text { and very long planks. Around this } \\
\text { central structure is a steep "shed-roof" } \\
\text { of ordinary flat planks ("clapboards," } \\
\text { to quote Eells), very "cheap" and short. } \\
\text { The steep pitch helps to carry off the } \\
\text { water, making unnecessary the use of the } \\
\text { more elaborate style of planks. This } \\
\text { lean-to was lined, wall and ceiling, ac- } \\
\text { cording to some informants, with matting, } \\
\text { which helped to exclude the weather. } \\
\text { A number of conflicting statements } \\
\text { came to light in making inquiry about } \\
\text { this type of house. For example, some } \\
\text { informants said the roof-planks ran } \\
\text { lengthwise of the structure, others said } \\
\text { they were crosswise; some said the pitch } \\
\text { was toward the rear, others that it was } \\
\text { toward one end. The explanation finally } \\
\text { supplied was of course a simple one. The } \\
\text { pitch of the roof was "away from the } \\
\text { rain," which in this region comes mostly } \\
\text { from the south. If in a given instance the } \\
\text { house faced another quarter, the pitch } \\
\text { of the roof was adjusted accordingly. In } \\
\text { some cases the "flat" roof sloped slightly } \\
\text { from the middle both ways. }\end{array}$ \\
\hline $\begin{array}{l}\text { I N D I A N N OT ES } \\
\text { and }\end{array}$ \\
\hline
\end{tabular}




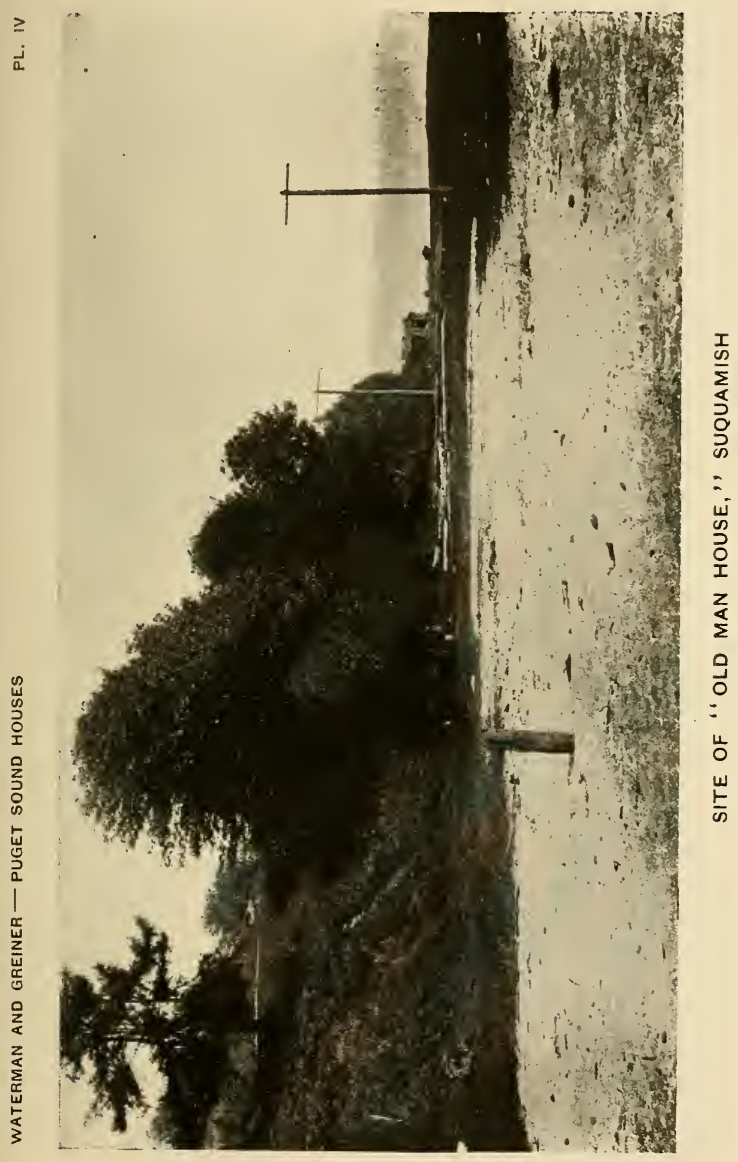











\begin{tabular}{|c|c|}
\hline GA M B R L FORM & 23 \\
\hline $\begin{array}{l}\text { Contradictory statements were also } \\
\text { made concerning the presence of a pit. } \\
\text { Usage may have varied somewhat. In } \\
\text { later times, especially, the pits may often } \\
\text { have been omitted. Some of the houses, } \\
\text { however, did have deep excavations. } \\
\text { Moreover, it is a fact that in many of the } \\
\text { old village-sites around the sound, the } \\
\text { house-pits are still to be seen at the } \\
\text { present day. The famous structure at } \\
\text { "Old Man House," on Port Madison } \\
\text { reservation, mentioned in every work } \\
\text { which deals with this region, had such } \\
\text { an excavation, } 5 \text { ft. in depth, according } \\
\text { to one informant. The remains of this } \\
\text { pit are visible in pl. v. This structure } \\
\text { also had a "lean-to," but only on its } \\
\text { landward side. In some cases the pits } \\
\text { were excavated to the full height of a } \\
\text { man. No ladders for descending into the } \\
\text { excavation are known to have existed. An } \\
\text { inclined plane served for access. For fur- } \\
\text { ther illustrations of the site of the "OId } \\
\text { Man House," see pl. Iv, vi. }\end{array}$ & \\
\hline AND MONOGRAPHS & \\
\hline
\end{tabular}




\begin{tabular}{|c|c|}
\hline 24 & PUGET SOUND HOUSES \\
\hline & $\begin{array}{l}\text { NATIVE WORDS FOR VARIOUS } \\
\text { TYPES OF HOUSES } \\
\text { We are now ready to take up the Indian } \\
\text { terms for "house." The word altu is } \\
\text { used for all habitations of whatever } \\
\text { material. Thus, a structure which is } \\
\text { stripped bare inside and swept out in } \\
\text { preparation for a "potlatch," is called } \\
\text { sgwi'gwi-alt " "distribution-house." } 28 \\
\text { Structures habitually used for such } \\
\text { potlatches were referred to as he' } q^{w} \text { al"al, } \\
\text { "big houses." There were usually only } \\
\text { one or two of these in a village, the poorer } \\
\text { people accommodating themselves as best } \\
\text { they could in a variety of "shacks." } \\
\text { Gibbs says that these great houses were } \\
\text { specially erected for festivals, and after- } \\
\text { ward dismantled. }{ }^{29} \text { It would be much } \\
\text { nearer the truth to remark that they were } \\
\text { built of permanent materials, but were } \\
\text { often partially dismantled, and the } \\
\text { planks used for temporary shelters, } \\
\text { during the season when no festivals were } \\
\text { in progress. A man "owned" the planks } \\
\text { which were used to cover his appointed } \\
\text { place in the big house. A temporary }\end{array}$ \\
\hline & INDIAN NOTES \\
\hline
\end{tabular}




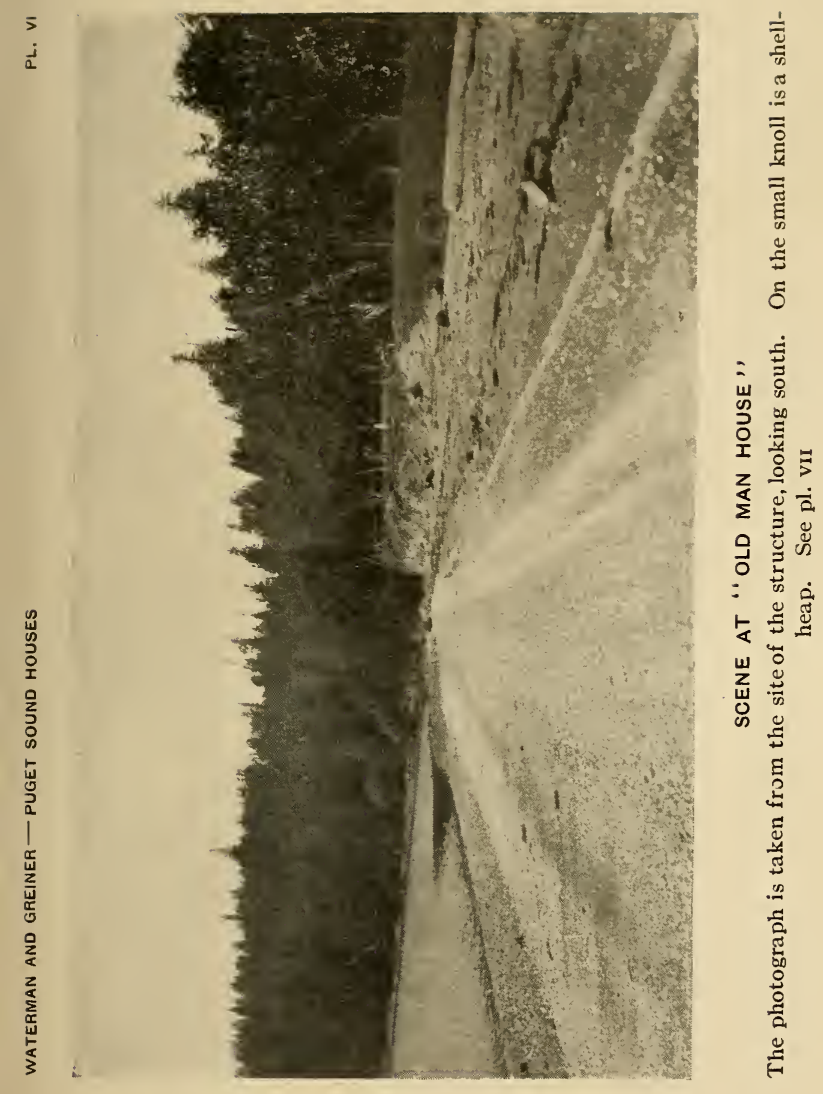





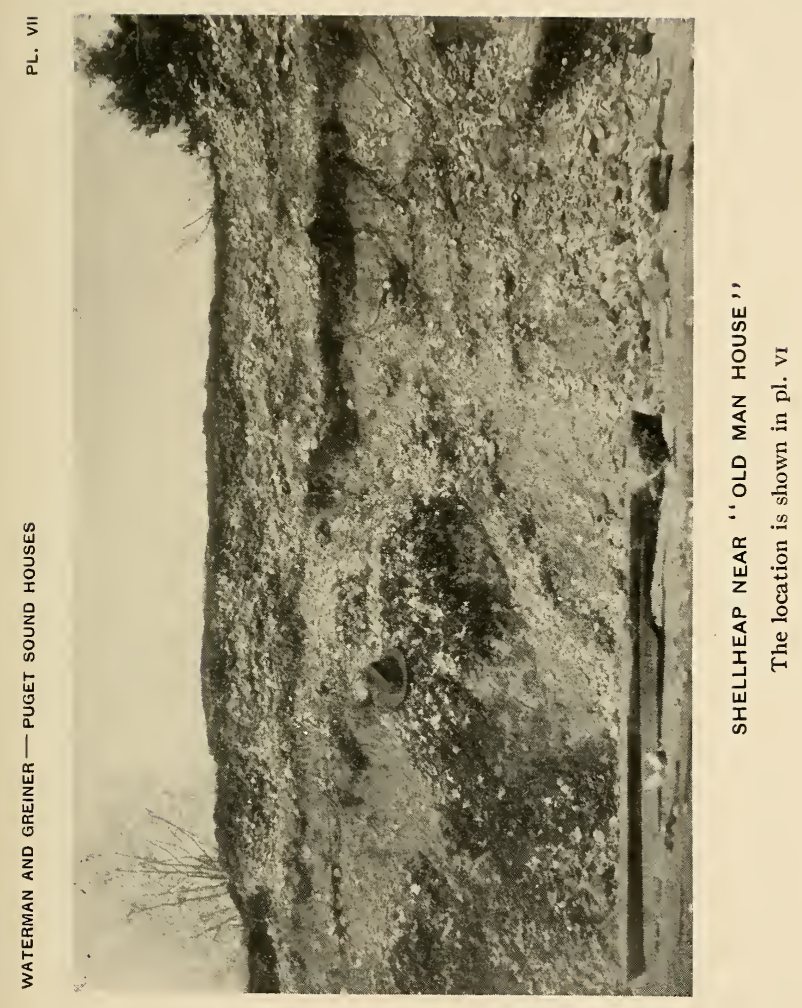



shelter for summer is called qwa'tak-alt . "mat-house," or volai't $x^{w}$, "warm weather shelter." A dwelling of "white-man's" architecture is called $p \Delta^{\prime} s \Delta d$-alt", "Boston-house," $p \Delta^{\prime} s \Delta d$ or $p a^{\prime}$ sıd being the Indian pronunciation of the name of the New England metropolis. This term alt is used also in names for those places where mythical beings are supposed to live; for example, xwiyaqw $\Delta^{\prime} d i$-a'l$t^{u}$, "Thunder his house."

The word for a permanent habitation of planks is $t \Delta^{\prime} s b \Delta d$, "cold-weather shelter," usually translated "winterhouse." This term applies to the permanent habitation, whatever the style of architecture. A special form of it (not described) was called kalasai'txw. The planks were often carried off to form temporary camps. It is worth remembering that a few of these planks represented a fortune to the Indian. They were split with great care out of cedar logs, and this operation required both time and skill. Not everyone could do it successfully. The Puget Sound planks

\section{AND MONOGRAPHS}




\begin{tabular}{|c|c|}
\hline 26 & PUGET SOUND HOUSES \\
\hline & $\begin{array}{l}\text { were not extraordinarily large, three feet } \\
\text { being a maximum width. At Cape } \\
\text { Flattery they were sometimes five feet } \\
\text { wide, and more. The Ferry Museum of } \\
\text { Tacoma has some splendid specimens on } \\
\text { display, which are fully that wide. Even } \\
\text { a narrow plank, however, was a treasure. } \\
\text { Poor people often did not have a plank } \\
\text { to shelter themselves with. In moving } \\
\text { about, the heavy planks were laid across } \\
\text { two canoes, forming a platform, upon } \\
\text { which the other effects could be piled. In } \\
\text { the warm season the big houses were } \\
\text { often deserted, the people being at distant } \\
\text { places where a large supply of food was } \\
\text { at the moment obtainable, either salmon } \\
\text { and other fish, or bulbs and berries. This } \\
\text { accounts for the remark made by Van- } \\
\text { couver that most of the villages scemed } \\
\text { to have been abandoned. He conjec- } \\
\text { tured }{ }^{30} \text { that prior to his visit there } \\
\text { must have been a pestilence. "Honey- } \\
\text { mooners" and the younger couples gener- } \\
\text { ally camped about, here and there, and oc- } \\
\text { cupied quarters in the larger housesonlyat } \\
\text { the time of potlatches or other gatherings. }\end{array}$ \\
\hline & I NDIAN NOTES \\
\hline
\end{tabular}




\begin{tabular}{|l|}
\hline C O N S T R U C T I O N \\
\hline CONSTRUCTION OF THE HOUSE \\
The following is an account of how the \\
house was constructed, step by step. \\
The figures in parentheses refer to a list \\
of native terms given on a later page. \\
A row of tall uprights (I) were planted \\
in the ground, some I 2 or I 4 ft. apart (see \\
pl. vilI). In rear of them a parallel row \\
of somewhat shorter posts was set, distant \\
some 25 or 50 ft. from the first row, ac- \\
cording to the size of the house. These \\
uprights were like very heavy planks. \\
Often they were more than 3 ft. wide and \\
8 in. in thickness. The inner surface of \\
these posts often bore a figure from 3 to \\
ft. long, carved in relief. Present-day \\
informants often refer to these carvings \\
as "totems." It is worth remarking that \\
they were quite another sort of thing \\
from the totemic crests of the tribes of \\
northern British Columbia and Alaska. \\
Snakes, fish, lizards, sea-mammals, and \\
human figures were delineated in these \\
carvings, but with nothing of the peculiar \\
"style" which is so characteristic of art \\
farther north. The design in each case \\
\hline A N D M O N O G R A P HS
\end{tabular}




\begin{tabular}{|c|c|}
\hline 28 & PUGET SOUND HOUSES \\
\hline e & $\begin{array}{l}\text { represented the owner's supernatural } \\
\text { helper, and was not a family crest. The } \\
\text { matter of obtaining these "helpers" was } \\
\text { part of an adolescence complex, with many } \\
\text { interesting features which cannot be dis- } \\
\text { cussed here. Inside of such a house, the } \\
\text { space between two posts was the especial } \\
\text { bailiwick of one man and his family. } \\
\text { The figure of the supernatural helper was } \\
\text { of ten set up alongside this "compart- } \\
\text { ment," and seems to have been looked } \\
\text { upon n a sense, and utilized, as a symbol } \\
\text { of ownership. } \\
\text { The principal task in erecting the house } \\
\text { was to lift into place certain great rafters } \\
\text { (2) which extended from front to rear of } \\
\text { the house, resting on uprights. These } \\
\text { rafters in the big structure at Port Madi- } \\
\text { son reservation were } 60 \text { ft. long and I } 7 \text { in. } \\
\text { through at the butt. The framework of } \\
\text { the house, then, consisted of a series of } \\
\text { bents, independent of each other, each } \\
\text { bent consisting of two "uprights" sup- } \\
\text { porting a slanting "rafter." The rafter } \\
\text { had "shoulders" at each end, so as to set } \\
\text { firmly on the uprights. Lighter beams or }\end{array}$ \\
\hline & I NDIAN NOTES \\
\hline
\end{tabular}




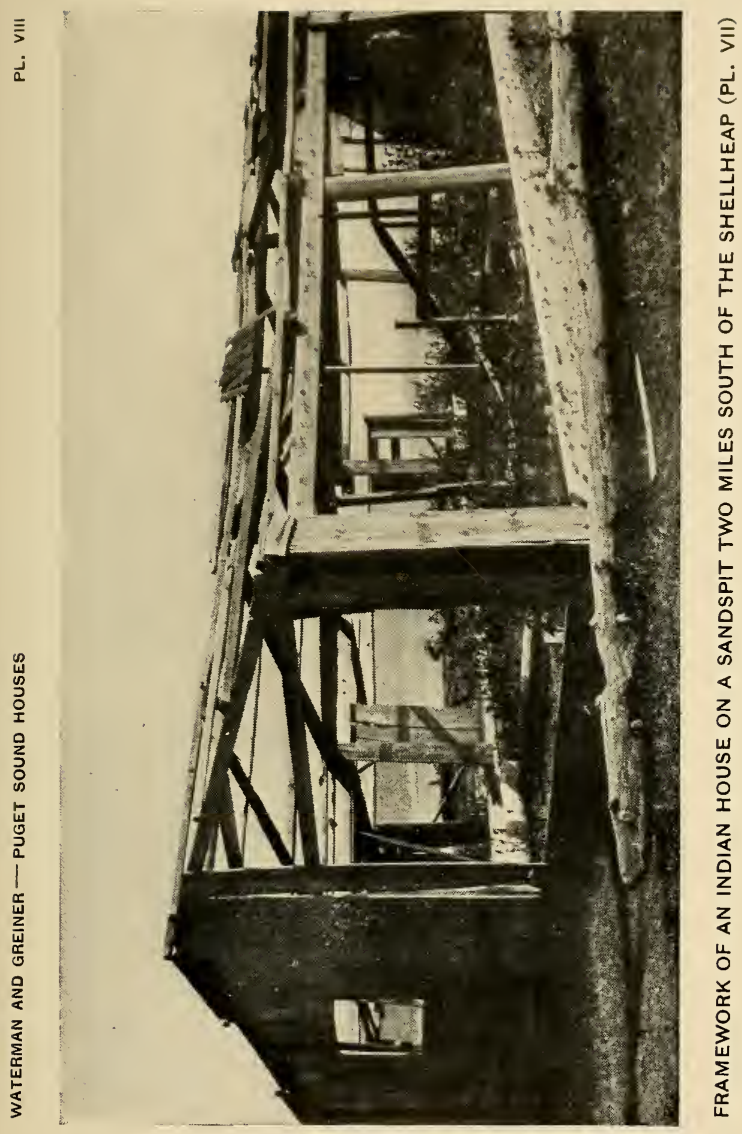





\section{CONSTR UCTION}

stringers were now placed lengthwise of the house, resting on top of the rafters. These would be called "sheeting" by a civilized carpenter. The stringer running along the eaves at the front of the house (3) was larger than the one for the rear (4). There were three or more rows of these longitudinal beams, depending on the width of the roof. They were the immediate support of the roof-planks. These roof-planks $(5,6)$ were quite elaborately wrought. They were split from cedar trees, in such a way that the edges were raised. They were made in two varieties, one kind having a deep trough (5) and the others a shallow one (6). Each kind had a special name. They were placed on the roof in two layers. In the lower layer the deeply-troughed planks were employed, and were placed with the trough upward, with enough longitudinal pitch so that the rain-water drained down their length. Over the cracks between those planks were placed other and shallower planks, in reverse position, that is to say, with the trough

\section{AND MONOGRAPHS}




\begin{tabular}{|c|c|}
\hline 30 & PUGET SOUND HOUSES \\
\hline & $\begin{array}{l}\text { Fig. 2.-Two types of roof-planks. } \\
\text { These roof-boards were held in place in } \\
\text { some cases by being weighted with stones. } \\
\text { In better houses a strip ( } 7 \text { ) was laid along } \\
\text { a row of boards, just over one of the } \\
\text { longitudinal plates. Holes were bored } \\
\text { through the planks, and a cedar withe (8) } \\
\text { was passed through these holes and } \\
\text { around the rafter below. These boards } \\
\text { were carefully treasured. The manu- } \\
\text { facture, as mentioned above, was a } \\
\text { tedious and somewhat difficult process. } \\
\text { After the planks were split from the log, } \\
\text { they were scraped down with a sharp } \\
\text { musselshell, and, in the case of fine speci- } \\
\text { mens, rubbed with "sandpaper" consist- }\end{array}$ \\
\hline & I NDIA N NOTES \\
\hline
\end{tabular}




\section{CONSTRUCTION}

ing of a piece of dog-fish skin. Where knot-holes existed in such planks, the carpenter sometimes made channels which would carry the water around them, instead of letting it drip through. In other cases the hole was covered with a "patch" (9), consisting of a clamshell. This shell was filled with blue clay, and then slapped down over the hole. When the mud dried the shell was held fast in its position. Planks which became cracked were carefully repaired. A row of perforations was made on each side of the crack, which was filled with pitch, and drawn together with lashings of twisted cedar-twigs. Pitch (I0) for this purpose has a special name. They sometimes filled a crack with long splinters (I I) so that the pitch would not drip through. After the resin hardened, the crack sometimes opened again, in which case they heated the end of a hard stick (12) and rubbed it in the crack to melt the pitch and fill the crack again.

In cases where a "lean-to" (I3) was added, the additional roof had a very

\section{AND MONOGRAPHS}




\begin{tabular}{|c|c|}
\hline 32 & PUGET SOUND HOUSES \\
\hline & $\begin{array}{l}\text { steep pitch, and was made of "ordinary" } \\
\text { planks (I } \text { ), without the upturned edges. } \\
\text { Eells applies to such "ordinary" planks } \\
\text { the term "clapboards." These boards } \\
\text { were fastened to the "plate" which ran } \\
\text { horizontally along the house at the eaves, } \\
\text { with ironwood pegs. As already men- } \\
\text { tioned, the walls consisted sometimes of } \\
\text { vertical and sometimes of horizontal } \\
\text { planks. Informants consulted near Se- } \\
\text { attle were more familiar with an arrange- } \\
\text { ment which they described as follows: } \\
\text { Boards (I5) were put as close together } \\
\text { as possible to compose the walls, standing } \\
\text { vertically. Over the cracks various odd } \\
\text { pieces were placed as battens (I6), then a } \\
\text { long strip (I } 7 \text { ) was run the length of the } \\
\text { house on the outside just under the eaves } \\
\text { to hold these upright boards in place. } \\
\text { It fitted up under the ends of the roof- } \\
\text { boards, and was lashed at intervals to the } \\
\text { "plate." Where a high wall existed, } \\
\text { several such strips were used, at differ- } \\
\text { ent levels. The wall-planks varied a good } \\
\text { deal in thickness. The strip held the } \\
\text { thick ones, but thinner ones would be left }\end{array}$ \\
\hline & I NDIAN NOTES \\
\hline
\end{tabular}




\section{CONSTRUCTION}

loose and rattling about. Wedges (18) in that case were driven up under the strip to give it a "purchase," or "bearing," on the loose elements.

When the wall-planks ran horizontally, a different style of fastening was, of course, required. This has been described by other writers. The essential matter is that upright poles (19) were set up and the planks stood on edge, one above another, between this pole and the house-frame (fig. I, $b$ ). Each plank was held in a sling made of cedar withes, in such a way that it overlapped the next plank, excluding the weather.

The main doorway (20) consisted of two uprights, with a heavy cross-piece, or lintel (2I). The top of this lintel had a channel or groove. Intc this groove fitted the lower end of the vertical wallplanks. Various other openings (22) were provided, depending on the size of the hou e. There was always a "back door" (23) leading into the forest. At the time of an attack, this back door, which led directly into the brush and the heavy

AND MONOGRAPHS 


\begin{tabular}{|l|l|}
\hline 34 & $\begin{array}{l}\text { P U G E T S O U N D H O US ES } \\
\text { timber, was a very popular exit. The } \\
\text { enemy, in trying to place a guard at this } \\
\text { back door in advance, to prevent escapes, } \\
\text { often gave alarm and put the household } \\
\text { on the alert. } \\
\text { The whole matter of doorways offers } \\
\text { some features of interest. Cook says that } \\
\text { the houses he saw at Nootka sound in } \\
\text { I778 had no doorways, properly speaking. } \\
\text { There were what seemed to be irregular } \\
\text { and chance apertures here and there, } \\
\text { through which the Indians passed in and } \\
\text { out. The houses described to us on } \\
\text { Puget sound and portrayed in the litera- } \\
\text { ture had quite elaborate entrances. It } \\
\text { may well be believed that Indian houses } \\
\text { in this region rapidly became more elab- } \\
\text { orate after the introduction of iron tools, } \\
\text { which made woodworking easy and rapid. } \\
\text { It is accordingly possible that the elab- } \\
\text { orate entrances described by recent } \\
\text { Indians are not really aboriginal. The } \\
\text { "Old Man House" at Port Madison } \\
\text { reservation had a kind of a maze through } \\
\text { which the visitor entered, consisting of a } \\
\text { series of parallel walls partly uncisvering }\end{array}$ \\
\hline \multicolumn{1}{|c|}{ I N D I A N N OT ES } \\
\hline
\end{tabular}




\section{CONSTRUCTION}

each other, around the flanks of which the visitor had to pass. In a dark place was a pit. The theory was that an enemy coming into the house, and being unfamiliar with it, would fall in this hole. Every well-built house was provided with a kind of hallway (24) formed by partitions (25) extending back into the house at each side of the entrance. This is said to have been for defense against enemies, but its military usefulness is hardly apparent. One of these houses, if once invested by a hostile force, could be defended only with difficulty. The enemy was as well off in any case as the people inside, and he could at any moment set the place on fire. The partition was more likely devised to exclude the cold wind. In aboriginal times there was nothing to close the aperture except a cedar-bark mat (26), and some kind of an additional windbreak would have been a great advantage. In more modern times heavy plank doors with iron hinges were hung at both ends of this hallway.

The interior arrangements of such a

\section{AND MONOGRAPHS}




\begin{tabular}{|c|c|c|}
\hline 36 & \multicolumn{2}{|c|}{ PUGET SOUND HOUSES } \\
\hline & 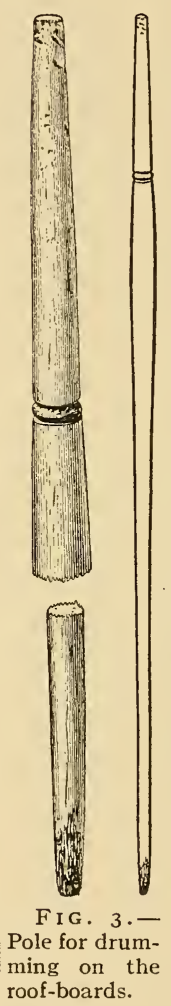 & $\begin{array}{l}\text { house depended on its size. } \\
\text { Where occupied by several } \\
\text { families, there was more than } \\
\text { one fire. Each fireplace }(27) \\
\text { had a big back-log (28). } \\
\text { When the fire was kindled, } \\
\text { someone would send a small } \\
\text { boy up on the roof to prop up } \\
\text { the edge of a plank with a } \\
\text { pair of small struts (29). } \\
\text { This made an exit (30) for } \\
\text { the smoke. If no boy were } \\
\text { at hand, they used a long } \\
\text { pole to move the planks } \\
\text { about, such poles being kept } \\
\text { for the purpose (fig. } 3 \text { ). Dur- } \\
\text { ing ceremonial performances } \\
\text { similar poles, quite elabor- } \\
\text { atelyornamented, werecarried } \\
\text { by performers. Holding these } \\
\text { poles (3I) upright they "drum- } \\
\text { med" by punching them ver- } \\
\text { tically against the roof-planks } \\
\text { (fig. } 2 \text { ). For the ordinary fire, } \\
\text { bark was the principal fuel, } \\
\text { because it made little smoke. }\end{array}$ \\
\hline & & DIAN NOTES \\
\hline
\end{tabular}




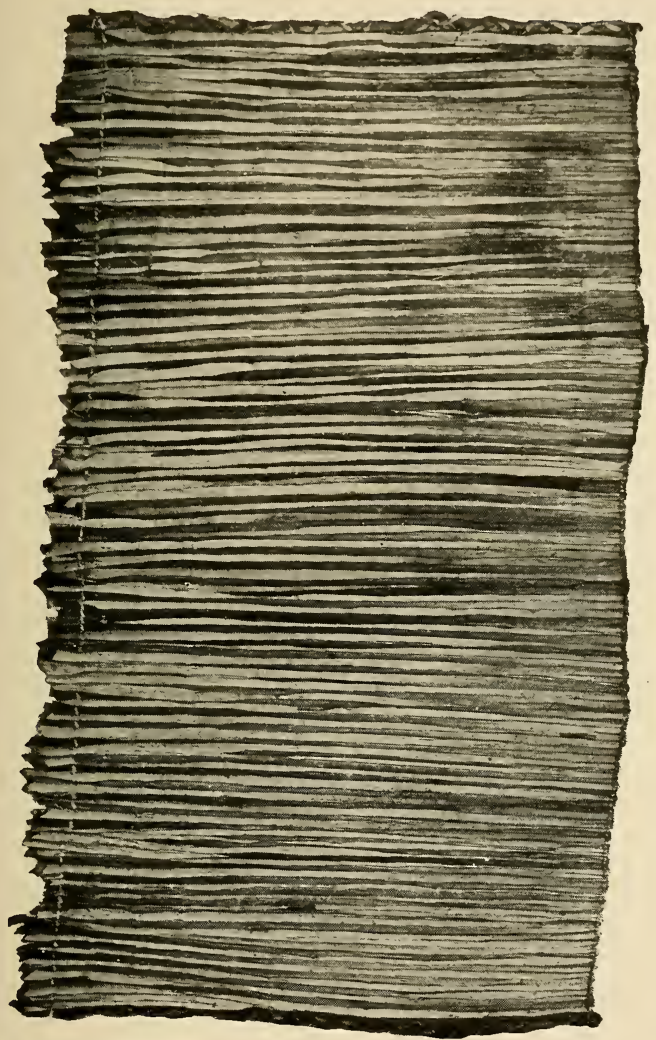

ORDINARY MAT USED AS A WALL COVERING

(Size, 2 ft. 9 in. by 4 ft. 9 in.) 



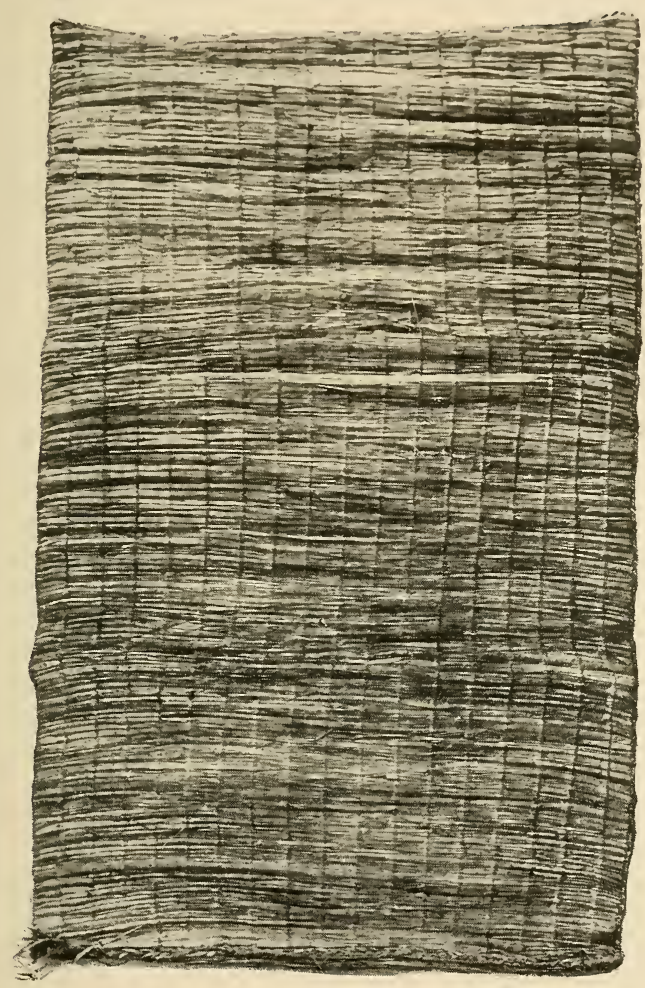

\section{SLEEPING MAT}

(Size, $3 \mathrm{ft} .9$ in. by $6 \mathrm{ft} .11 / 4$ in.) 



\section{CONSTR UCT I ON}

Numerous other features were constant in all these houses. The walls were lined with ordinary mats (32) of cattail rushes, which were utilized not only in this way, but for a variety of other purposes. They consist of rushes which are placed horizontally and held together by a vertical warp of twine made of fibers split from rushes (pl. Ix). Around the wall extended a platform (33) for beds. This was $3 \frac{1}{2}$ or $4 \mathrm{ft}$. wide,,$^{31}$ and the occupants lay with their sides to the fire. Thick and very springy mats (34), made of cattails especially for the purpose, were spread for the sleepers on the planks (pl. $\mathrm{x})$, and another mat was usually rolled up to form a pillow. There were no partitions between the cubicles of different families. Underneath the bedplatform, which was a foot or more from the ground, various pieces of property were stored. Above the bed-platform and extending completely around the house was a shelf (35), about three feet wide, made of small poles. This shelf was suspended from the rafters, and pos-

\section{AND MONOGRAPHS}




\begin{tabular}{|l|l|}
\hline 38 & $\begin{array}{l}\text { P U G E T SO U N D H O US ES } \\
\text { sessions endless in variety were stored } \\
\text { upon it. } \\
\text { From the native standpoint the center } \\
\text { and soul of the house was a great rack } \\
\text { for drying fish. Cross-pieces (36) were } \\
\text { extended from the one side of the house } \\
\text { to the other, at the level of the lower } \\
\text { eaves. The cross-piece rested at the rear } \\
\text { of the house upon the lowest log of the } \\
\text { "sheeting," while its other end was sup- } \\
\text { ported by withes from the roof. Poles } \\
\text { (37) were then laid lengthwise of the } \\
\text { house, about I6 in. apart, resting on these } \\
\text { cross-pieces. Salmon brought in by the } \\
\text { fishermen were cut open and the back- } \\
\text { bone taken out. They were then skew- } \\
\text { ered through their tails with a stick (38). } \\
\text { The "stick" of fish was then laid across } \\
\text { between two of the longitudinal poles, } \\
\text { and the fish left to cure in the smoke. } \\
\text { This lower rack (39) just described was } \\
\text { only for fresh fish. A higher rack (40) } \\
\text { was used in a similar way for curing the } \\
\text { backbones, which did not need to be so } \\
\text { heavily smoked. Further aloft still, was } \\
\text { a third rack (4I), for salmon which were }\end{array}$ \\
\hline \multicolumn{1}{|c|}{ I N D I A N N OT ES } \\
\hline
\end{tabular}




\section{HOUSE PARTS}

half-cured. Thoroughly cured fish were removed from over the fire and placed in special racks (42) for preservation.

A narrow strip of wood was suspended by withes some 4 or $5 \mathrm{ft}$. (43) below the drying frame. On this were hung pieces of meat or fish which were intended to be used at once. Hung from this pole was a "towel" (44) of shredded cedar-bark, used for wiping the fingers.

The house-pit (45) contained all the hearth fires. Descent from the outer ground level into this excavation was either by a sloping ramp or a flight of steps (46).

NATIVE TERMS FOR THE PARTS OF THE HOUSE

The native terms appear in the following list in the order in which they are mentioned above.

\section{Structural Parts}

I. Uprights, sqw'a'lad.

For the house front, $t a^{\prime} d z u s$.

For the rear wall, kw' $a^{\prime} d a t c$.

\section{AND MONOGRAPHS}




\begin{tabular}{|c|c|}
\hline 40 & PUGET SOUND HOUSES \\
\hline & 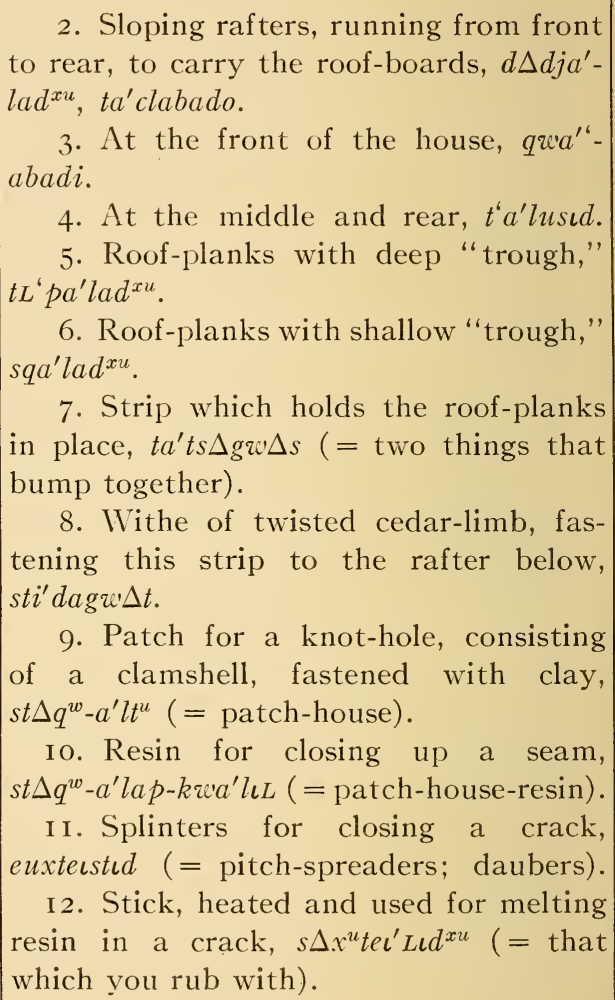 \\
\hline & I NDIAN NOTES \\
\hline
\end{tabular}




\begin{tabular}{|c|c|}
\hline HOUSE PARTS & 41 \\
\hline  & \\
\hline AND MONOGRAPHS & \\
\hline
\end{tabular}




\begin{tabular}{|c|c|}
\hline 42 & PUGET SOUND HOUSES \\
\hline &  \\
\hline & INDIAN NOTES \\
\hline
\end{tabular}




\section{HOUSE-L I F E}

for drying fish, ula'dtwad (= salmon-for).

37. Lengthwise poles resting upon (36), ca'labud (= things which one pushes through or inserts).

38. Stick upon which fish were skewered, cut ${ }^{\prime} \Delta^{\prime} l c \iota d$ ("= things which keep something open or spread).

39. Rack for drying fresh fish, $L p o^{\prime}$ sali.

40. Higher rack, for backbones, which were cured separately, xa'xali (xako, backbone).

4I. Rack for half-dried salmon, sihai'.

42. Rack for cured salmon, $L k a^{\prime} t \Delta d$ ( $=$ where things are piled; cf. number 35 above).

43. Pole for fresh meat and fish for immediate use, $c u b u$ 's $\Delta d$ ( = for cooking).

44. "Towel" of shredded cedar-bark, pas (= wiper).

45. House-pit, $t c a^{6} a^{\prime} l t^{u}$ (= dig-house). 46. Steps leading down into pit, $c u^{\prime} l^{\prime} c a$.

\section{HOUSE-LIFE}

Visitors who came to this region in early times spoke in terms of contempt of the native structures. They were full

\section{AND MONOGRAPHS}




\begin{tabular}{|l|l|}
\hline 44 & $\begin{array}{l}\text { P U G E T S O U N D H O US ES } \\
\text { of cracks, and at the same time full of } \\
\text { smoke. They were "ill-built," and in } \\
\text { form they were skewed. Moreover, a } \\
\text { good deal of dirt and confusion reigned } \\
\text { within. The principal occupation on all } \\
\text { hands was the curing of fish, and ob- } \\
\text { servers speak in wondering phrases con- } \\
\text { cerning the odor that surrounded and } \\
\text { permeated Indian establishments. The } \\
\text { life of the Indians in many ways was hard, } \\
\text { and their mode of existence was not ideal. } \\
\text { On the other hand, the denunciatory } \\
\text { remarks can be explained in large part as } \\
\text { contempt felt by a people five-eighths } \\
\text { civilized for people only half-civilized. } \\
\text { There was a great deal in Indian life } \\
\text { that was pleasant, and much in the rela- } \\
\text { tions of the Indians to each other that is } \\
\text { pleasing. } \\
\text { For example, no child in an Indian } \\
\text { household was ever struck, and no child } \\
\text { was ever sent to school. Yet most } \\
\text { children grew up to be disciplined mem- } \\
\text { bers of society, and each of them devel- } \\
\text { oped into an excellent workman at some } \\
\text { difficult trade. If any one did not, the }\end{array}$ \\
\hline \multicolumn{1}{|c|}{ I N I A N N OT ES } \\
\hline
\end{tabular}


chances are he starved to death. In addition to learning with great accuracy how to manufacture and manipulate complicated tools of the chase, certain modes of action were powerfully inculcated. Forms of behavior, in many respects as complicated as our own, were instilled, without the victim of the process being really aware of it.

We find that this sense of discipline appeared among even the youngest members of a household. Mothers used to explain to very young children the necessity of keeping still in emergencies-for example, during attacks by the enemy. Haida and "Stickeens" (Tsimshian) used to come down from the north on raids. When houses were suddenly assaulted, the people would try to get into the brush behind the village. "Mother can't carry you all," a woman would explain to her children, "so when I put you into any place that seems safe, stay there and be quiet until I come after you." When an emergency came, a child snatched at midnight from his dreams and pitched

\section{AND MONOGRAPHS}




\begin{tabular}{|c|c|}
\hline 46 & PUGET SOUND HOUSES \\
\hline &  \\
\hline & I NDIAN NOTES \\
\hline
\end{tabular}




\section{H O US E-L I F E}

Indians!" would be the reproach directed at a lazy or a careless youngster. One of the informants, a half-breed woman, inherited from her white father a narrow, high nose, with a marked notch where it met the forehead, very different from the true Indian nose, which is very low and broad at this point. Her "chest-bone" also jutted forward somewhat prominently. When she was a child, her mother, if seriously provoked, would address her as "Ctcat $\alpha$ " ("notchy!") or "Tsudzi'gw $\Delta s$ " ("sticking out in front!"), instead of calling her by her proper name. "Well-bred" children would not help themselves to any kind of food from the store-house, especially if the older people were away. They always waited, sometimes in serious hunger, until the elders returned. There was always, of course, some riffraff and no-account people who "did not know how to bring up children correctly."

There was somewhat similar discipline also among the older people of the group. In the early morning the oldest man in a

\section{AND MONOGRAPHS}




\begin{tabular}{|l|l|}
\hline 48 & \multicolumn{1}{|c|}{ P U E T S O N D H O US ES } \\
\hline $\begin{array}{l}\text { house would take a light switch and go } \\
\text { around smacking it against the walls. } \\
\text { This was the signal, "everybody out!" } \\
\text { Men and boys went into the water of the } \\
\text { Sound for a bath, while women went up } \\
\text { the creek. Nobody was exempt in this } \\
\text { matter, not even children. } \\
\text { Many of the customs which we asso- } \\
\text { ciate with "family" life were lacking } \\
\text { altogether. Husband and wife never } \\
\text { addressed each other by their proper } \\
\text { names, saying simply "old man" or "old } \\
\text { woman." A somewhat affectionate term } \\
\text { was sometimes used, meaning "spouse." } \\
\text { There was little privacy in the big houses. } \\
\text { Families even shared hearth-fires in } \\
\text { many cases. They reckoned kinship } \\
\text { very closely, however, and the "better" } \\
\text { families have even yet a strong feeling } \\
\text { for the importance of genealogies. Their } \\
\text { kinship terms have many interesting } \\
\text { features: for example, brother addressed } \\
\text { brother by one term, and sister addressing } \\
\text { sister used the same term; while brother } \\
\text { addressing sister used a different term. } \\
\text { They also had a special set of terms }\end{array}$ \\
\hline \multicolumn{1}{|c|}{ I N D A N N O T ES } \\
\hline
\end{tabular}




\section{I S T R I B U T I O N}

which were used between relatives by affinity, after the connecting relative had died. Marriage was usually between people of separate establishments or separate groups. There was no tribal organization of any sort. So far as any social fabric existed, it was based on the family and the house-group.

\section{DISTRIBUTION OF THE VARIOUS FORMS OF HOUSES}

It is a striking fact that while the "shed" type of house is used about Puget sound and for some distance northward, it is replaced in the most northerly regions by a "gabled" form. Gabled houses of excellent construction are characteristic of all the tribes north of the Comox. The shed type is pretty closely identified with the Salish tribes, a fact already noted by Boas and Hill-Tout. From the Salish, apparently, it spread to their neighbors within the general area about Puget sound, such as the nonSalishan Nootka, Makah, Chimakum, and Quilliute. It looks very much as

\section{AND MONOGRAPHS}




\begin{tabular}{|c|c|}
\hline 50 & PUGET SOUND HOUSES \\
\hline & $\begin{array}{l}\text { though this gabled house were an older } \\
\text { form in this region, having apparently } \\
\text { had at one time a very extended distri- } \\
\text { bution along the coast, from Mount Saint } \\
\text { Elias in Alaska to Humboldt bay in Cali- } \\
\text { fornia. Along the whole stretch of coast } \\
\text { included between these two extremes, we } \\
\text { find rectangular plank-houses, with no } \\
\text { interruption. At both ends of the area, } \\
\text { moreover, these rectangular houses take } \\
\text { the form of gabled structures with paired } \\
\text { ridge-poles, vertical wall- and roof-planks, } \\
\text { and an interior pit reached by a flight of } \\
\text { steps. This is certainly a strong argu- } \\
\text { ment for the supposition that in former } \\
\text { times there was a continuous distribution } \\
\text { of such houses over the whole region. } \\
\text { In a limited area, merely, on Vancouver } \\
\text { island and about Puget sound, the gabled } \\
\text { form is replaced by a shed-shaped } \\
\text { dwelling, less elaborate in its construc- } \\
\text { tion. The examples of this shed form } \\
\text { examined more than a hundred and forty } \\
\text { years ago by Captain Cook, were, as a } \\
\text { matter of fact, quite crude. This might } \\
\text { suggest that the type was still evolving }\end{array}$ \\
\hline & INDIAN NOTES \\
\hline
\end{tabular}




\section{B I B L I O G R A P H Y}

at that time. The whole situation suggests very strongly that the "shed" structure is intrusive in this area, having been brought perhaps from the interior by the Salish, and modified by conditions encountered on the coast: such conditions as the previous existence there of habits of working in wood. If this is the case, the intrusive peoples have out-Heroded Herod in one matter: they gave their structures much greater size than did any other stocks of the Pacific coast. So far as that is concerned, these Salish shed-houses seem to have been the largest structures erected anywhere in the New World.

WORKS REFERRED TO IN THE TEXT BANCROFt, Hubert Howe

I886 The native races [of the Pacific States]. Five volumes. [These form volumes I-5 of a thirty-volume series entitled "The Works of Hubert Howe Bancroft," San Francisco, I886-I 888.]

BOAS, FranZ

I889 The houses of the Kwakiutl Indians. Smithsonian Institution, Proceedings of

AND MONOGRAPHS 


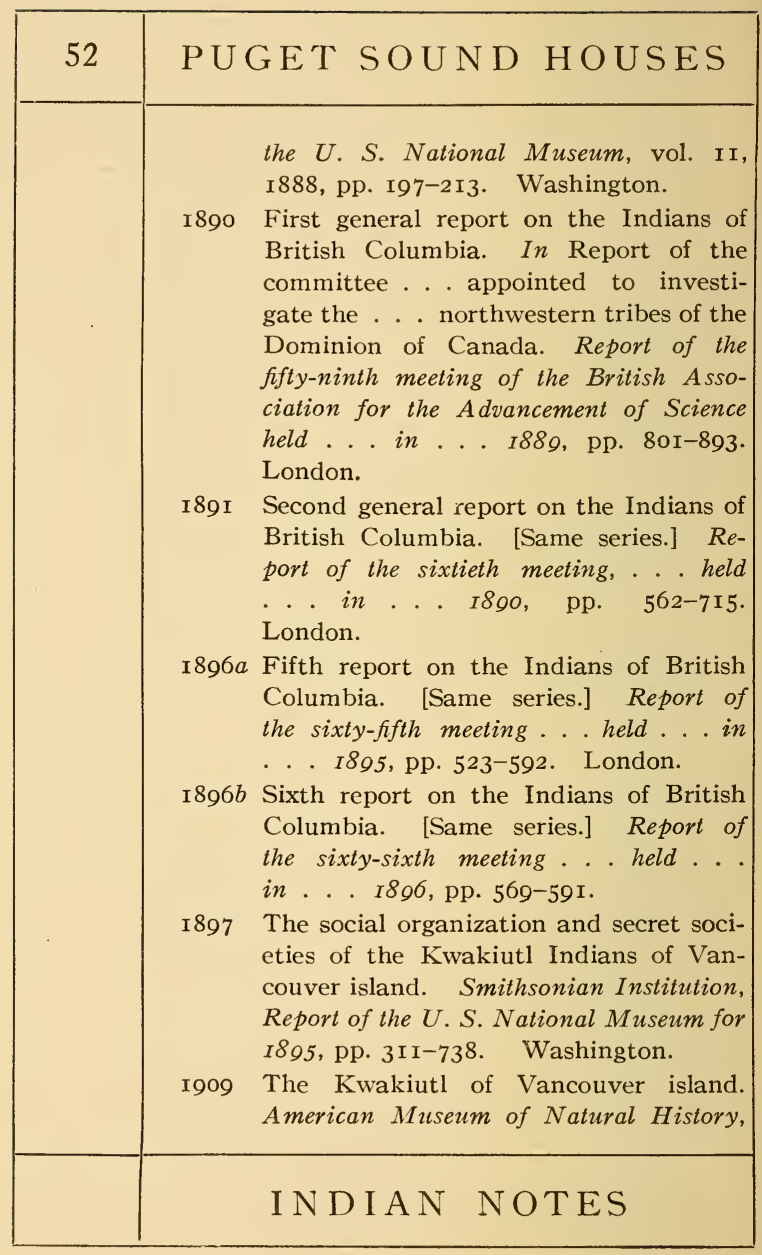




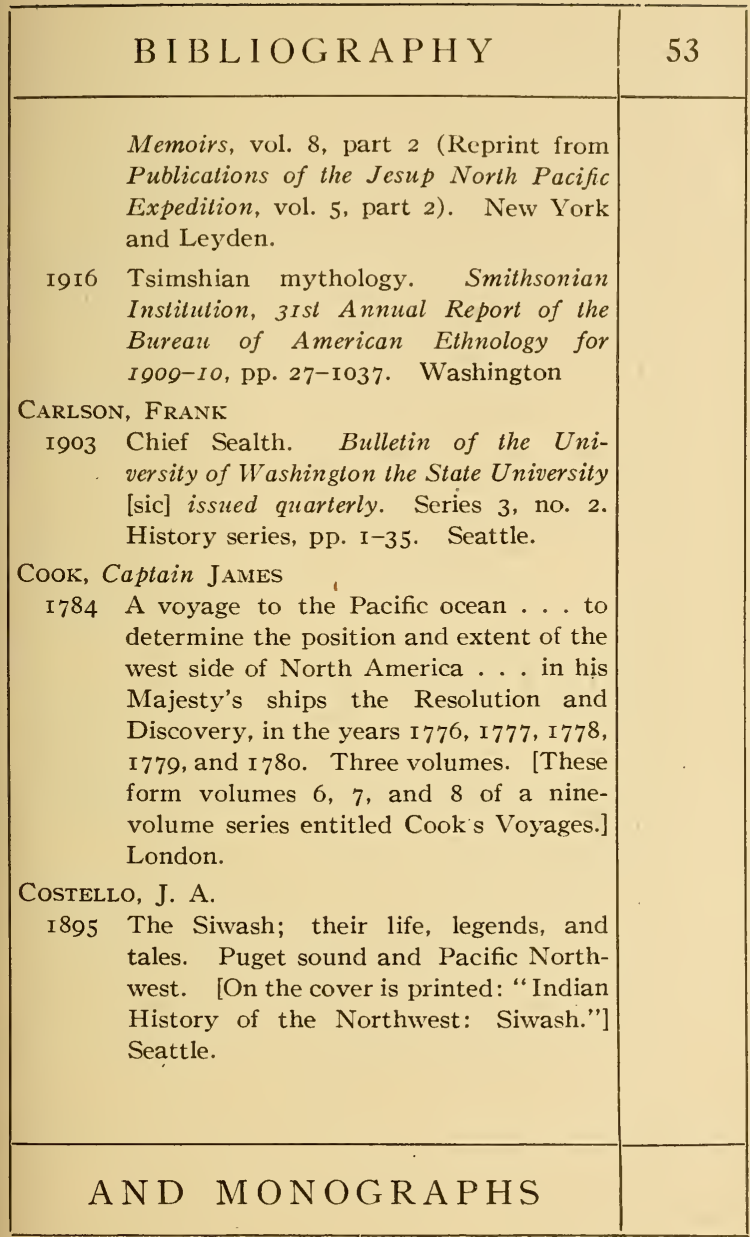




\begin{tabular}{|c|c|}
\hline 54. & PUGET SOUND HOUSES \\
\hline & $\begin{array}{l}\text { CURTIS, EDwARD S. } \\
\text { I907-I9I6 The North American Indian; } \\
\text { being a series of volumes picturing and } \\
\text { describing the Indians of the United } \\
\text { States and Alaska, written, illustrated } \\
\text { and published by Edward S. Curtis, } \\
\text { edited by Frederick Webb Hodge, fore- } \\
\text { word by Theodore Roosevelt, field re- } \\
\text { search conducted under the patronage of } \\
\text { J. Pierpont Morgan. Twenty volumes. } \\
\text { [I volumes issued to date.] } \\
\text { DENNY, EMILY INEz } \\
\text { I909 Blazing the Way, or True stories, songs } \\
\text { and sketches of Puget sound and other } \\
\text { pioneers [sic]. With illustrations by the } \\
\text { author and from authentic photo- } \\
\text { graphs. Seattle. } \\
\text { The Twana, Chemakum and Challam } \\
\text { I889, Myron } \\
\text { Indians of Washington Territory. An- } \\
\text { nual Report of the Smithsonian Institu- } \\
\text { tion for I887, pp. 6o5-68I. Washing- } \\
\text { ton. } \\
\text { FRASER, SIMON } \\
\text { I889 Journal of a voyage from the Rocky } \\
\text { mountains to the Pacific coast, I8o8. } \\
\text { In Les Bourgeois de la Compagnie du } \\
\text { Nord-ouest. Recits de voyages, lettres } \\
\text { et rapports inédits relatifs au nord- } \\
\text { ouest Canadien. Première série, pp. } \\
\text { I56-22I. Quebec. }\end{array}$ \\
\hline & I NDIAN NOTES \\
\hline
\end{tabular}




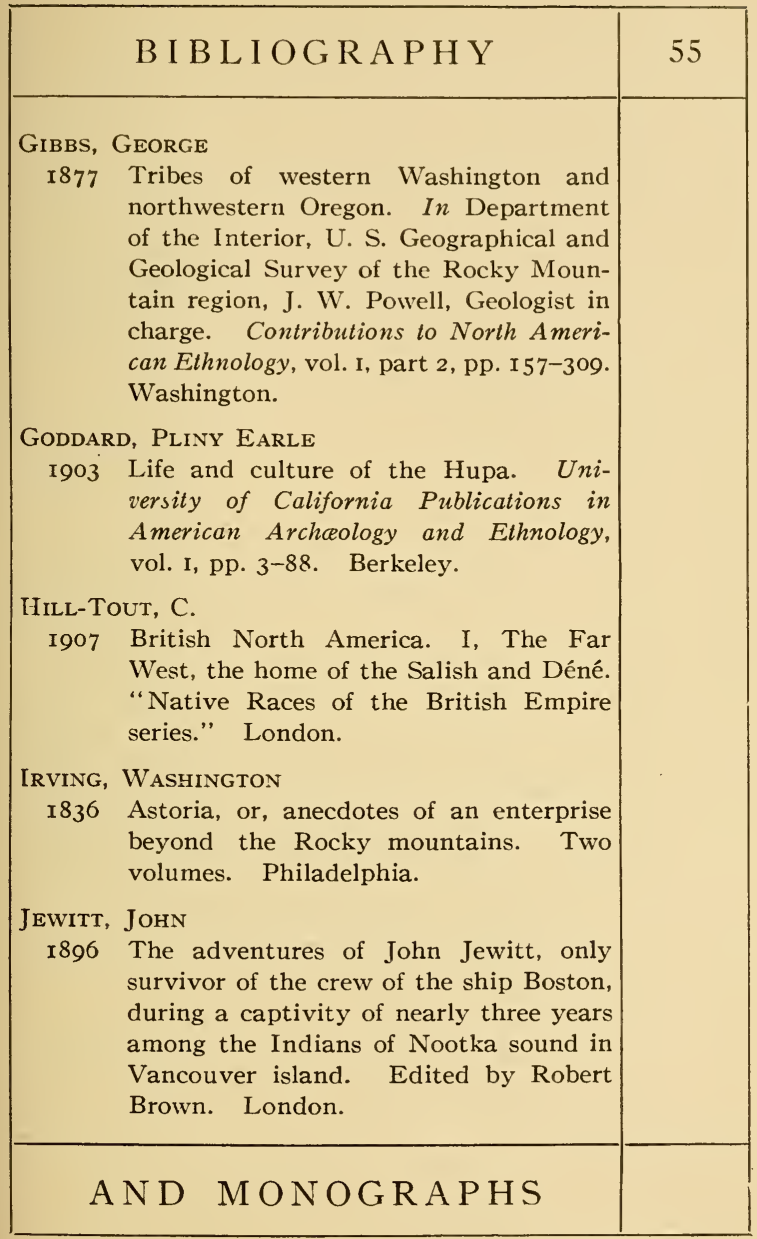




\begin{tabular}{|c|c|}
\hline 56 & PUGET SOUND HOUSES \\
\hline & $\begin{array}{l}\text { KELLEY, HALL J. } \\
\text { I83I A general circular to all persons of good } \\
\text { character who wish to emigrate to the } \\
\text { Oregon Territory . . By order of } \\
\text { the American Society for encouraging } \\
\text { the settlement of the Oregon Territory } \\
\text {. . instituted in Boston, A. D. I829. } \\
\text { Charlestown. } \\
\text { KROEBER, A. L. } \\
\text { Handbook of California Indians. (In } \\
\text { press.) } \\
\text { LEwIS AND CLARK } \\
\text { I904 Original journal of the Lewis and Clark } \\
\text { Expedition, I8o4-I8o6. Printed from } \\
\text { the original manuscripts in the Library } \\
\text { of the American Philosophical Society } \\
\text { and by direction of its committee on } \\
\text { historical documents, together with } \\
\text { manuscript material of Lewis and Clark } \\
\text { from other sources, including note- } \\
\text { books, letters, maps, etc., and the } \\
\text { Journals of Charles Floyd and Joseph } \\
\text { Whitehouse. Now for the first time } \\
\text { published in full and exactly as written. } \\
\text { Edited, with introduction, notes, and } \\
\text { index, by Reuben Gold Thwaites, LL.D. } \\
\text { Eight volumes. New York. } \\
\text { NiBLACK, AlBERT P. } \\
\text { The Coast Indians of southern Alaska } \\
\text { and northern British Columbia . . . } \\
\text { Smithsonian Institution, Report of the }\end{array}$ \\
\hline & I NDIAN NOTES \\
\hline
\end{tabular}









\begin{tabular}{|c|c|}
\hline 58 & PUGET SOUND HOUSES \\
\hline & $\begin{array}{l}\text { History, Memoirs, vol. 8, part I (Re- } \\
\text { print from Publications of the Jesup } \\
\text { North Pacific Expedition, vol. 5, part I). } \\
\text { New York and Leyden. } \\
\text { VANCouver, Captain GEORGE } \\
\text { I798 A voyage of discovery to the North } \\
\text { Pacific ocean . . performed in the } \\
\text { years I79o, I79I, I792, I 793, I 794, and } \\
\text { I795, in the Discovery sloop-of-war and } \\
\text { the armed tender Chatham. Three } \\
\text { volumes. London. } \\
\text { VICTOR, Mrs FRANCES FuLLER } \\
\text { I870 The River of the West." Life and } \\
\text { adventures in the Rocky Mountains } \\
\text { and Oregon, embracing events in the } \\
\text { life-time of a mountain-man and pioneer, } \\
\text { with the early history of the north- } \\
\text { western slope, including an account of } \\
\text { the fur traders, the Indian tribes, the } \\
\text { overland immigration, the Oregon mis- } \\
\text { sions, and the tragic fate of Rev. Dr. } \\
\text { Whitman and family. Also a descrip- } \\
\text { tion of the country, its conditions, pros- } \\
\text { pects and resources; its soil, climate, } \\
\text { and scenery, its mountains, rivers, } \\
\text { valleys, deserts, and plains, its inland } \\
\text { waters and natural wonders, with num- } \\
\text { erous engravings. Published by sub- } \\
\text { scription only. Hartford, Conn., New- } \\
\text { ark, N. J., Toledo, O., and San Fran- } \\
\text { cisco. }\end{array}$ \\
\hline & I NDIAN NOTES \\
\hline
\end{tabular}




\section{NOTES}

WATERMAN, T. T.

Notes on Yurok culture. Indian Notes

WORK, JOHN

and Monographs. (In press.)

I908-I9I5 “Journal of John Work," I824I826, edited by T. C. Elliott. Washington Historical Quarterly. The Washington University [sic] State Historical Society, vol. 3, pp. I98-228; vol. 5, pp. 83-I I 5, 163-I9I, 258-287; vol. 6, pp. $26-49$.

\section{NOTES}

I. I9II-I6, vol. VIII, p. 47 .

2. I909, p. 369 .

3. Swan, I857, p. I Io; Bancroft, I886, vol. I, p. 23I; Kelley, I830, p. 7 I ; Victor, I870, p. I25. 4. Loc. cit.

5. Swan, I857, pp. 32, 33I, 339 (Chehalis); Swan, I857, p. I Io (Chinook); Work, I908-I5, vol. III, p. 206 (Chinook); Kelley, I830, p. 7 I (Indians of Oregon).

6. I 886 , vol. I, p. 23 I.

7. I 857 , p. I I

8. Lewis and Clark, I904, vol. II, p. I09; Victor, I870, p. I25; Bancroft, I886, vol. I, p. 231 ; Irving, I836, p. 206.

9. I 877 , p. 215 .

I o. Boas, I $896 a$, p. 8 г 8 .

I $а a$. Boas; I89I, p. 563 .

I I. Cook, I 784, p. 3 I 4 . 


\begin{tabular}{|c|c|}
\hline 60 & PUGET SOUND HOUSES \\
\hline &  \\
\hline & I N D I A NOTES \\
\hline
\end{tabular}




\section{NOTES}

29. I 877, p. 215 .

30. I 798, pp. 252, 254 (May I 792).

3I. Eells, I889, p. 324; Curtis, I9II-I6, vol. IX, p. I 57 .

32. See Waterman and Collaborators, Native Houses of Western North America, Indian Notes and Monographs, I920. 


SMITHSONIAN INSTITUTION LIBRARIES

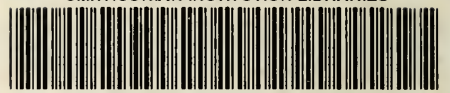

39088015285240 